\title{
ПРОСТІР ЗАДЗЕРКАЛЛЯ У ПОЕЗІЇ СВІТЛАНИ АНТОНИШИН
}

\author{
Леслава Кореновська \\ Педагогічний університет ім. КНО \\ Краків, Польща \\ ORCID 0000-0003-1372-0667
}

\section{THE SPACE OF THE MIRROR BACK IN SVITLANA ANTONYSHYN' POETRY}

\begin{abstract}
In Svitlana Antonyshyn's poetry we can immerse ourselves in the dramatized dynamic space of the mirror back, which is the main theme of Svicha-Do-La's collection and conveyed through the laconic text, ontologically rich metaphors, noun sentences and condensed emotions of the poetess herself, which generates suggestibility. The space of the mirror back is on the other side of the mirror and is a back projection of everything that falls within the object, and has the ability to reproduce the imprint. The poetry of the Ukrainian poetess is a kind of attempt to cross the threshold of the invisible, to look into the mirror of events that have passed into the past or are happening now, to enter the multifaceted inner world of the lyrical character in order to explain all his secret.
\end{abstract}

Key words: the space of the mirror back, interpretation, contemplation of space, poetess' intention.

Є літературні твори, які проживаєш слово за словом, рядок за рядком, сторінку за сторінкою; їхню енергію вбираєш усім своїм єством, майже фізично переносиш себе в простір авторського уявлення, який нерідко складається із миттєвостей, спостережень, емоцій, деталей зовнішнього та внутрішнього світів. Як писала Марина Цвєтаєва, читання - це творчий, співтворчий процес, важка розумова робота. Якщо втомилися від читання, значить читали добре і добре читали. Таке плідне творче стомлення від співпраці з автором під час ознайомлення 3 його твором (творами), безумовно, розширює горизонти уяви, пропонує зрозуміти та трактувати уже існуючі погляди, ситуації та обставини 3 іншої перспективи, дає можливість по-новому сприймати те, що відбувається у собі та довкола. Автором, твори якої полонять і втягують 
у вербальний простір, можна назвати сучасну українську поетесу Світлану Антонишин ${ }^{1}$.

Її остання поетична збірка 3 химерною назвою, схожою то на паліндром, то на криптограму Свіча-До-Ля включає вірші останніх десяти років і складається із трьох розділів: Віддзеркалене задзеркалля. Поезія 2013-2016 років; Осіння Коронація долі. Поезія 2006-2010 років; Свіча під небом грозовим. Поезія 2010-2013 років.

Без сумніву, назва збірки викликає зацікавлення як своїм дивним значенням, так і графічним оформленням. Слово свічадо в українській мові означає, з одного боку, свічник для декількох свічок, а з іншого дзеркало, вірніше віддзеркалення чи відображення. Другий компонент заголовка - це слово До-Ля, тобто дует першої і шостої музичних нот, що в результаті утворює слово доля. Характерно, що середній компонент назви збірки До є спільним: останнім складом у слові Свіча-До і першим у слові До-ля. Дефіси, графічно зафіксовані у заголовку, розтягують зорове сприйняття назви, сповільнюють темп читання, додають мелодійності. Об'єднуючи два слова візуальним сприйняттям, поетеса, здається, просить затриматись, намагаючись натякнути, що мова піде про складне: про багатоликість у самотності, про безліч сходинок в одновимірній площині, про різнобічність у простоті, про миттєвість у вічності. Передчувається тонка авторська гра, що нагадує запрошення у театр одного героя, у простір задзеркалля, у світ авторського бачення, експліцитно невидимий, але імпліцитно багатий і цікавий.

У віршах збірки можна виділити спільний елемент - це відображення у просторі задзеркалля. Характерно, що це не просто віддзеркалення оточуючих нас предметів (їх зовнішній вигляд, поведінка людини, міміка, жести) у дзеркалі, але також невидимий світ почуттів, хвилювань, радості і смутку, світ спогадів, фантазії, уявлень, недомовленості. Простір задзеркалля автор подає у широкому аспекті - перед нами констеляція нагромадженого роками досвіду поетеси, багата філіація, переосмислення і поновне відчуття всього, що життя дало і відняло, всього, що несе день прийдешній і чому вчить минуле. Антонишин пропускає через своє

\footnotetext{
Світлана Антонишин народилась у “пушкінський” день - 19 жовтня - 1959 року в місті Броди Львівської області, закінчила факультет журналістики Київського державного університету ім. Т. Шевченка. Працює у галузі поезії, прози та літературної критики. Антонишин $є$ автором двох книг прози та семи поетичних збірок, серед яких варто назвати Янгол Самотнього неба, Запитання до вічності, Знак Сізіфа, Падіння скелі, Ображена трава, Свіча-До-Ля. Поетеса $є$ лауреатом кількох престижних літературних премій: ім. М. Шашкевича Благовіст, ім. П. Тичини, ім. Б. Нечереди та ін. 31999 р. С. Антонишин - член Національної Спілки Письменників України. Останнім часом живе і творить у рідному місті.
} 
трепетне серце побачене, почуте, відболіле, майстерно переробляє весь цей матеріал у своїй творчій лабораторії.

Творчість Світлани Антонишин унікальна. У своєму інтерв’ю поет Роман Кудлик дав влучну характеристику творчості колеги по перу:

Елегантна ошатність форми, трепетна делікатність, непомильна влучність кожного слова, глибока самобутність думки розливають той чарівний аромат, який називається справжньою поезією².

Проза і поезія Антонишин становить багатий матеріал для дослідників. Скажімо, метамова поетеси вимагає максимальної концентрації i внутрішньозорового сприйняття прочитаного, яке нерідко важко намалювати в уяві. Метамова поетичних рядків завжди залишає простір для до-осмислення, до-малювання, до-переживання. Варто згадати про онтологію внутрішнього світу Антонишин, яку не завжди легко розшифрувати в вербальній канві творів, особливо прихований підтекст, лексичні та граматичні тонкощі, численні ремінісценції і алюзії, несподівано захоплюючі метафори, гносеологічні та аксіологічні чинники 3 метою вірної інтерпретації задуму автора і розширення горизонту сподівань (X.-P. Яусс).

У даній статті зосередимося на такому аспекті творчості Світлани Антонишин як простір задзеркалля, який злокалізований по іншу сторону дзеркала і являє собою зворотну проекцію всього, що потрапляє у рамки предмета, що має здатність відтворювати відбиток. У своїх праця ${ }^{3}$ я відмічала, що мотив дзеркала $є$ одним із провідних у творчості поетеси. Зорова дія, спрямована на поверхню дзеркала, дає можливість не тільки охопити оком побачене ззовні, але проникнути за обрій та узріти те, що знаходиться потойбіч. Дзеркало не обмежує фантазію - воно швидше копіює друге $Я$ людини, фотографує його відображення. Таким чином поширюється композиційний простір вірша для створення ілюзійної нескінченності відбитків, художній простір подвоюється шляхом відображення картин (предметів) у дзеркалі. Юрій Лотман вважає, що “дзеркало, одначе, може грати іншу роль: подвоюючи, воно спотворює і тим самим оголює те, що зображення, яке здається «натуральним», стає проекцією, яка несе в собі деяке мовне моделювання"4.

2 Поезія Світлани Антонишин устами працівників Бродівської ЦРБ, [в:] Роеzіуа Svitlany Antonychyn ustamy pracivnykiv Brodivskoi CRB, [інтернет-джерело:] https://www. youtube.com/watch?v=RwxBW2ru_rw, доступ 12.10.2020.

Л. Кореновська, Метамова поезії Світлани Антонишин, “Дзвін” (Часопис Національної Спілки письменників України) 2013, № 7 (837), с. 139-146; Л. Кореновська, Простір внутрішнього світобачення Світлани Антонишин, “Слово і час" 2015, № 5 (653), с. 16-28. 4 Ю. Лотман, Семиосфера. Культура и взрыв. Внутри мыслящих миров. Статьи. Исследования. Заметки (1968-1992), Санкт-Петербург 2000, с. 69. 
Тут ми маємо справу з так званим простором споглядання (Володимир Топоров), тобто тією категорією змісту свідомості, яка виступає еквівалентом реального простору в непросторовій свідомості і має безпосереднє відношення до розуміння та інтерпретації тексту. "Уявлення не існує у просторі, але в уявленнях $\epsilon$ простір: те, що в них $\epsilon$, являється як просторова тривалість. Запропонована просторовість і $є$ простір споглядання. Це - вражаюче пристосування до зовнішнього світу; інакше світ не міг би являтись як «зовнішній»"

Доцільно нагадати, що архетип дзеркала тісно зв'язаний із процесом мислення та уявлення. Людина бачить у дзеркалі взаємодію Я і $\mathrm{He}$ Я, одиничної особистості та світового цілого. Віддзеркалення ніколи не $\epsilon$ правдивим, нерідко воно може розколюватись на безліч відбитків, в яких може загубитися сам об' єкт споглядання. Не випадково появився міф про дзеркало Діоніса. Згідно тексту, титани відволікли увагу Діоніса за допомогою дзеркала, в якому бог розчленувався на численні відображення, і пошматували його. Ольга Чулкова вважає, що цей сюжет можна інтерпретувати як деміургічну дію, самопожертву божества при творінні космосу, але водночас це приклад того, як небезпечно розчинятися у дзеркальній поверхні'.

Дзеркальний простір вбирає у себе світ, виповнюється ним, але нічого не віддає, оскільки його перманентною характеристикою $є$ порожнеча. За дзеркальною поверхнею немає глибини. Все, чим володіє дзеркало, - відображений у ньому світ. Всі предмети чи істоти, які потрапляють у рамки простору дзеркала чи в його потойбічну темноту, тонуть, не знаходжуючи сенсу. Підтвердження сказаному можна знайти у творчості багатьох письменників і поетів (Двійник Федора Достоєвського, Ніч перед Різдвом Миколи Гоголя, Портрет Доріана Грея Оскара Уальда, поезія Всеволода Іванова, Олександра Блока, Сергія Єсєніна та ін.).

Антонишин свідомо розширює амплітуду онтологіії мотива дзеркала, ніби запрошує відкрити невидимий світ простору задзеркалля. У вірші По-бачення із циклу Мовчання свічад читаємо:

\section{Вдивлявся до болю,} до скрику,

до сполотнілого серця.

Відображення було знайомим,

\footnotetext{
5 В.Н. Топоров, Пространство и текст, [в:] Текст: семантика и структура, отв. ред. Т.В. Цивьян, Москва 1983, с. 227.

6 О. А. Чулкова, «Живые зеркала». Мифология и метафизика отраженного, [в:] Альманах «АКААНМЕІА». Материальи исследования по истории платонизма, вып. 3, Санкт-Петербург 2000, [інтернет-джерело:] http://platoakademeia.ru/index.php/ru/ academeia/item/39-academeia_3_10, Доступ: 19.08.2020.
} 


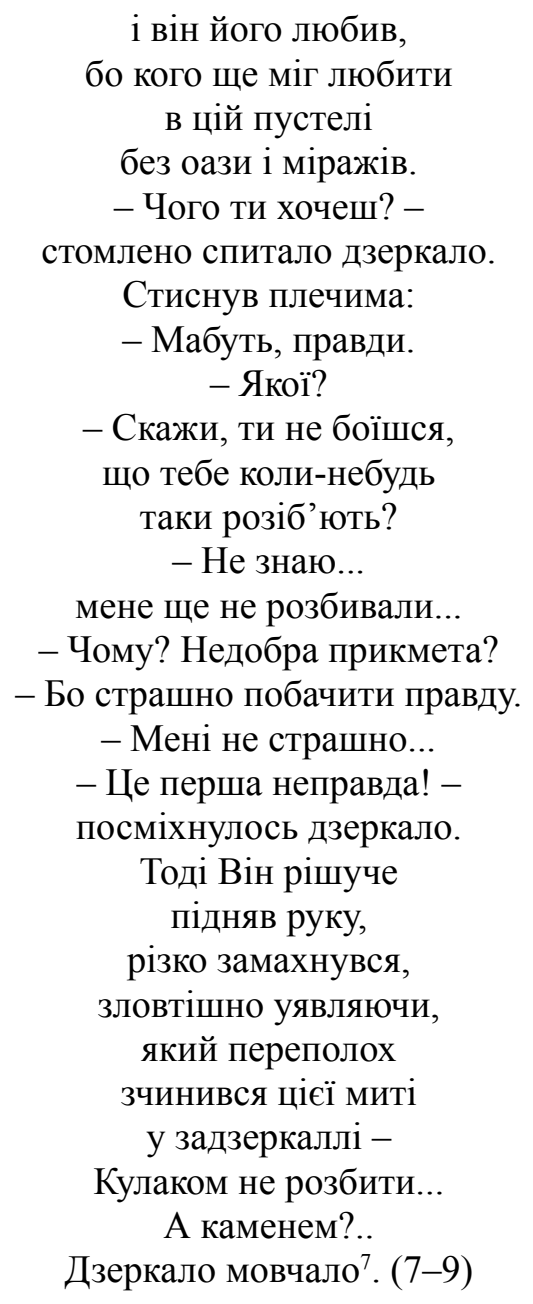

Наведений приклад є підтвердженням думки Фрідріха Шиллера про те, що космос схожий на гігантського Нарциса, який розглядає свої власні відображення у людській свідомості. Дзеркала, як і водяна гладка поверхня, здатні віддзеркалювати все, що осідає на них. Визнання ліричного героя, що йому подобається власне відображення у дзеркалі, оскільки воно йому знайоме і приємне, викликає асоціації з міфологічним Нарцисом, закоханим у власне відображення, а також у певній мірі з Чорним чоловіком Сергія Єсєніна з однойменної поеми, де ліричний герой

\footnotetext{
7 Тут і далі сторінки наведених прикладів із збірки поезії С. Антонишин Свіча-До-Ля подаються у дужках та цитуються по: С. Антонишин, Свіча-До-Ля, Київ: Український пріоритет 2017.
} 
веде діалог із своїм дзеркальним двійником, а в кінці розбиває дзеркало, усвідомлюючи, що Чорний чоловік - це він сам у стані сп'яніння. Антонишин розширює простір віддзеркалювання за допомогою введення діалогу між ліричним героєм-дзеркалом і відображенням у ньому (Biн). Розмова торкається таких проблем, як правда-брехня, знищення і мовчання. Згідно думки поетеси, страх побачити голу правду бере верх і вибирає менш болючий варіант - неправду: 3 нею легше, вона на поверхні, видима і вигідна. Натомість правда не завжди приваблива та зрима, її не відразу помічають, у неї треба вникнути, зайти в глибину задзеркалля душі, думок, спогадів. Що стосується мотиву знищення у вигляді розбитого дзеркала, то для виконання цієї руйнівної дії поетеса вплітає у текст два варіанти: уявний аспект, при якому розбите дзеркало може зчинити переполох у просторі задзеркалля, тобто небажане приховане стане видимим; риторичне питання, що стосується заміни предмета, яким можна розбити дзеркало, - замість кулака камінь (А каменем?..). Відповіддю стає багатослівність мовчання. Як було уже зазначено, у творчості Антонишин мотив мовчання - невід'ємна частина літературного процесу поетеси, при чому динамічна і творча. Це стан душі, коли можна почути звуки навколо, а в пам'яті оживає все замилуване серцем. Це час, коли збирається аксіологічне каміння знань і мудрості, щоб згодом бути розкиданим у поетичних рядках. Простір задзеркалля у наведеному прикладі вміщає приховану правду, небажану, головним чином, самому персоніфікованому дзеркалу (Бо страшно побачити правду.).

Інтермецо

Промінь дзеркало розбудив.

Біла сукня. Зелені очі.

На підбори немає сил...

Срібний глек сам себе розбив:

Хтось наврочив. Таки наврочив

Диво-дзеркальце знає все,

Тож прикинулось німотою... (11)

Наступний фрагмент поезії - низка дієслів та іменників, які у своїй послідовності творять картинку-кадр. Логічною кульмінацією у наведеному прикладі стає різкий звук розбитого глека (сам себе розбив). Натомість обрамлення у вигляді дієслів із значенням приглушеного звучання (розбудив, наврочив) плавно переходить у мовчання дзеркала: Тож прикинулось німотою..., щоб не видати себе, не відкрити правду, як диво-дзеркало із відомої казки про Мертву ияарівну та сім богатирів. Поетеса пропонує відгадати загадку, яка прихована у просторі задзеркалля і назовні зафіксокана підказкою у вигляді констатації наочних відображень: Біла сукня. 
Зелені очі, та емоційної канви, що потребує інтепретації, розшифрування, переходу в простір задзеркалля: На підбори немає сил..., делікатно натякаючи, що мова йде про драму кохання та несповненої мрії про шлюб.

Продовженням теми дива-дзеркала, що може сказати правду, $є$ поезія Жінка спинилася. Фрагмент із вірша:

\section{Дзеркало, цить!}

Вчися брехати, жаліти. Це ж просто...

Все віддаєш за оманливу мить,

Все віддаєш, хоч ніхто і не просить...

...У задзеркаллі сльотава ява...

Там тільки тіні, яким вже не страшно...

Жінка спинилась... Вона ще жива.

Дзеркало, любе, скажи: «Ти прекрасна!»

Знаю, рум'яна. Жорсткий макіяж.

То тільки час ходить світом без гриму...

Те саме небо, та інший пейзаж,

Плавно зникомий, ну, майже незримий -

Мов у свічаді. Ілюзія, мить.

Жінка спинилась. Зітхнула: «Приємлю»...

Кажуть, що дзеркалу пам'ять болить...

Тіні безстрашні навідують землю,

Щоб повернутись із жмутком новин. (12)

Уже з перших рядків слух коробить емоційний сплеск, в якому звучать різкі слова-команди, скеровані до дзеркала: Цить! Та Вчися брехаmи, жаліти. Далі спостерігаємо метаморфозу в інтонації звертання до дзеркала - перехід до благання: Дзеркало, любе, скажи: «Ти прекрасна! У кінці поезії лірична героїня погоджується із власним безсиллям i $з$ покорою приймає ненависний власний відбиток, який їй безпочуттєво холодно сервує дзеркало: Жінка спинилась. Зітхнула: «Приємлю». Проміжки опадання емоцій лірична героїня заповнює рефлексією, що звучить у мінорному тоні та передає невимовний смуток літньої жінки за молодістю і красою, які канули у бездонність часу, залишаючи по собі тіні: «У задзеркаллі сльотава ява.. / Там тільки тіні, яким вже не страшно...». Простір задзеркалля стає свідком метаморфози зовнішності жінки, фотографією іiі актуального вигляду та пам'яттю прожитого та пережитого. Текст вірша - це свого роду декламований міні-монолог, роль слухача якого бере на себе дзеркало, а відповіддю стає мовчання.

Зміст вірша Хронічна тиша нагадує колаж реплік: пропозиція офіціанта (Ваш чай, мадам...), побажання незнайомої людини (То хай зігріє вас політ печалі...) та дві репліки ліричної героїні, з яких одна - це відпо- 
відь офіціантові (Я не просила чаю!), а друга - рефлексія філософського характеру (Нам дзеркало простило всі сивини). Лапідарність текстового матеріалу збагачена сугестивністю підтексту, який носить рефлексійно-філософський характер. Відхід близьких, рідних чи знайомих передається за допомогою порівняння з птахами, які відлітають.

Хтось відлітає. Поодинці. Клином.

«Ваш чай, мадам...». «Я не просила чаю!»

«То хай зігріє вас політ печалі...»

«Нам дзеркало простило всі сивини». (216)

У поезії Перед склом Антонишин із перших слів називає дзеркало прозорим бар'єром не до подолання, звертається до нього як до неприятеля (Сміється, клятий!); на перше риторичне питання Чого він хоче ще, якої плати? дає відповідь, щоб змогти самій висловити наболіле (Bce віддано, нічого не сховати, / Хіба щзо душу настіж розірвати...), у свою чергу, друге - Чомусь стоїи і дивишся на скло? - задає собі сама в пошуках виходу із складної ситуації. При цьому поетеса потребує якщо не співрозмовника, то принаймні слухача для своїх визнань-сповідей - Щоб хтось почув із вічної завії.

Перед склом (фрагмент)

Бар'єр, який ніколи не здолати.

Прозорий, аж скляний. Сміється, клятий!

Чого він хоче ще, якої плати?

Все віддано, нічого не сховати,

Хіба що душу настіж розірвати...

Чомусь стоїш і дивишся на скло.

Розбити б... Так, без відчаю й надії,

Ну, просто, аби хоч якась подія,

Щоб хтось почув із вічної завії

Захриплий голос стомленого змія

Чи регіт невідмоленого Вія...

... А ти стоїш і дивишся на скло...

Агов! Ау! Скажіть, ви справді люди?

Чомусь так зимно у космічній буді,

Хоч вий за співчуттям... Його не буде!

- Стихає порох вічної погоні...

А ти стоїш і дивишся на скло... (176)

Мелодійність наведеного вище тексту створюється завдяки алітерації (збіг сонорних приголосних $M, r, \mu$ і дзвінкого г) та жіночої рими: 
стомленого змія і невідмоленого Вія, де названі істоти викликають асоціації із відомим хтонічним гоголевським героєм та знаним спокусником із Едему. Метафоричність простежується у словосполученнях, що, наприклад, стосуються всесвіту, який названий космічною будою. Безнадійність ситуації, в яку потрапляє лірична героїня під час перебування у просторі задзеркалля, викликає бажання присутності когось живого, про що свідчать вигуки Агов! Ау!. При переході в новий простір людина стає позбавленою колишньої неусвідомлюваної опори у вигляді старого простору з його властивостями та наповненням, тому її нерідко охоплює страх. Незаповненість і нескінченність простору задзеркалля, особливо його порожнеча (страх порожнечі) позбавляють людину можливості орієнтації, тобто співвіднесення себе $з$ простором. Людина почувається загубленою у новому просторі, навіть саме пізнання якого в цьому випадку ставиться під сумнів. Запитання Скажіть, ви справді люди? скоріше всього не вимагає відповіді, оскільки в наступних рядках появляється рефлексія із емоційним забарвленням зневіри, загубленості, колапсу, світового катаклізму, нерідко спричиненого людською байдужістю: Хоч вий за співчуттям... Його не буде!, тому що, як констатує Антонишин, фатально дрібніють люди, обростають колючками і панщеріють на очах (поезія Чужіємо).

Продовженням наведеного прикладу можна вважати вірш із риторичним запитанням у назві Кому живу?, що викликає асоціацію із заголовком роману Генрика Сенкевича Quo vadis? і містить стилістичну квазі-помилку (пор. Для кого живу? Кому жити? і тп.). Очевидно, для поетеси це запитання має вельми глибокий сенс: кому передати роками нагромаджені знання і досвід; 3 ким поділитися думками, що не дають спокою; кому адресувати сльози з викарбуваними на них палаючими словами; кому показати віддзеркалене задзеркалля душі, тобто перед нами знову ж таки потреба присутності адресата, при чому адресата, який зможе заглянути в простір задзеркалля і знайти у ньому відповіді на свої і поетеси запитання.

\author{
Кому живу? \\ Спитай у дзеркала: \\ Там силуети, сріблом вишиті, \\ І твій автограф на сльозі: \\ «Кому живу?» (72)
}

Як пише Людвіг Вітгенштейн, існує так зване спустошеня простору, тобто зникнення притаманних йому предметів чи живих істот. Це породжує тривогу і неспокій, які можуть проявлятись у десперативних зовнішніх діях: крик, сплеск емоцій, пошук когось, хто б міг заповнити порожнечу, 
або ж мовчання. На жаль, життя позбавлено дару цілковитого наповнення простору: воно діє в стосунку до нього вибірково і непомітно, адже навіть між найближчими формами життя (скажімо, сусідніми в класифікаційній схемі) існує просторовий зазор, зяяння ${ }^{8}$ У відношенні до поезії такою щілиною між просторами туm і там можна окреслити момент рішучості чи вагання зробити крок у задзеркалля, що власне і $є$ наміром поетеси.

Персоніфіковані дзеркала в поезії Атракціон характеризуються динамічністю: беруть на себе роль арбітра та критика божевільного світу. До слова, майже у всіх віршах Антонишин відчувається несприйняття абсурдності сьогодення. Розшифровуючи метафоричність наведеної нижче поезії, спостерігаємо умовну передачу ролей. На початку зустрічаємо криві дзеркала, тобто такі, що здатні деформувати відображення із ціллю розсмішити чи налякати об'єкт споглядання. У вірші вони грають роль à la прокурора, який короткими називними реченнями осуджуює все абсурдне, брудне, неправильне, що відбувається у різних сферах суспільства (Катаракта. Звих. Абсурд абсурдів.). У другій половині вірша лірична героїня переймає головну роль - запрошує криві дзеркала як співтоваришів історії переступити поріг задзеркалля, адже там місие $\epsilon$ для всіх. Дзеркала стають очевидцями прожитого, подій чи ситуацій (Ідем гуртом крізь вибухи жалю), свідками прихованості почуттів, невимовленості важливих слів, свічадами викривленого мовчання.

\section{Атракціон}

Криві дзеркала в божевільний світ

Вдивляються, аж луска амальгама.

Самі себе не можуть зрозуміть:

Чи рух не той, чи в них стареча драма -

Яви і суті. Катаракта. Звих.

Абсурд абсурдів. Склеротична яма.

У задзеркаллі місце $є$ для всіх,

Але ж...але ж...Вони сьогодні з нами...

... Ідем гуртом крізь вибухи жалю,

На магмі незастиглої печалі

Лишаємо немовлене: «люблю...»

I тричі непроказане: «Що далі?»

Криві свічада криво так мовчать,

Немов від себе крізь віки втікають. (14)

Перша строфа наведеного вірша - всі усім чужі-перегукується із відомими рядками поезії Ліни Костенко Усі усіх не люблять - це біда. Пря-

8 Л. Витгенштейн, Логико-философский трактат, Москва 1958, с. 79. 
ме призначення атракціону як місця для розваг трансформується у локус жаху, запроектованої чи запланованої кимось безвихідності. Згідно 3 традиційною моделлю, простір скоріше за все асоціюється із волею (не свободою), що передбачає екстенсивну дію, позбавлену цілеспрямованості, і конкретне оформлення (туди! геть!) ${ }^{9}$. Натомість у просторі задзеркалля Антонишин варіантом покинути метафоричний замкнутий простір (У тім атракціоні без дверей) виступає небажання знайти двері, а не логічний природний рух вирватись назовні.

Бо разом йдем, а всі усім чужі...

Була кімната сміху, стала...тихо...

... «Не наступіть серцями на ножі».

Сміятись пізно, може, навіть дико -

У тім атракціоні без дверей...

(Принаймні їх уперто не знаходять). (15)

Для Антонишин вихід із абсурдної ситуації обігрується у дусі християнської віри: Колись Господь дзеркала прибере. Але на разі залишається ляк і покора, які породив страх: у поезії це виражено запереченнями Не перейду (мислиться, із простору задзеркалля у нормальність реальності), не подолаю (невіра у власні сили або освідомлення фізичної чи психічної немочі зробити сміливий крок уперед). Тому звучить пропозиція-прохання до дзеркала взяти за руку, бути поруч, повірити, що лірична героїня знає вхід і вихід, проведе крізь вічність $і$ крізь мить.

Колись Господь дзеркала прибере,

А поки що...а поки що... хай ходять.

Не перейду, не подолаю, не...

Візьміть за руку, хай не буде страшно.

Візьміть за руку. Підемо разом.

Я проведу. Я знаю вхід і вихід.

Вас проведу крізь вічність і крізь мить. (23)

На думку В. Топорова, пренатальна пам'ять може фіксувати наявніть двох різних просторів - зовнішнього і внутрішнього: "Потреба в співвіднесенні себе і свого життя із цілим деяких абсолютних цінностей робить людину чуйною до космічного ритму і дбайливою до всього того,

9 В. Н. Топоров, О пространстве, пути, великих текстах, вечной жизни и бессмертии, [в:] „Secret Code”, [інтернет-джерело:] https://alekseygodin.wordpress.com/2017/12/08/ toporov/, Доступ: 29.10.2020. 
що може розглядатися як еталон орієнтації у просторі та часі" ${ }^{\prime 10}$. Простір задзеркалля у поезії Антонишин можна трактувати і як необ'єктивний ігровий простір, під яким розуміється друга реальність, уявний локусний вимір, здатний входити у свідомість адресата та вібрувати в ньому. У певній мірі це внутрішній голос, що закликає знівелювати протиріччя між суб'єктом і об'єктом, а разом із тим сприяє створенню тексту як результату співпраці автора і читача ${ }^{11}$.

У вірші Задзеркалля спостерігаємо передислокацію двох локусів (Країна і Дім), які сприймаються в одному семантичному плані, у простір задзеркалля і з метою експлікувати досвід ліричної героїні, який сплетений із закоренілих забобонів, що ще рятують душу, сухої інформації із преси (Завтра Хроніки напишуть), народної пісенності про білу фату, що посивіла. Весь вірш тричі перетинають повторюючі варіативні строфи Вишня біла. Стіни білі. Небо біле. - називні речення, які розсвітлюють вербальну канву поезії, а водночас цементують архітектоніку твору, що притаманно елементам-константам, наділеним символікою чистоти, весни, надії на щасливе прийдешнє.

У Країні, що чомусь назвалась Домом,

В тім свічаді, що розбити не посміла.

Все наївне і невчасне, і невміле,

Мов фата, яка - ви чули? - посивіла,

Чи вино навпіл з палючим самогоном.

Вишня біла. Стіни білі. Небо біле.

І сміється те свічадо, ледь не плаче:

«Забобони ще рятують скло і тишу...»

Чи надовго? Завтра Хроніки напишуть

Про Країну, де й страхи на ладан дишуть,

I дадуть своїм рядкам баладний зачин:

«Біле небо. Білі стіни. Біла вишня...»

Жовта свічка в срібнім відсвіті мовчання.

Синій грім і сивий спалах у каміні.

В задзеркаллі - запитально - очі й тіні:

«А живуть іще лелеки в тій Країні

Чи давно крилом махнули на прощання?»

...Біле небо. Біла вишня. Білі стіни... (97)

Із сказаного вище можна констатувати, що в поезії Світлани Антонишин простір задзеркалля, масштабно впроваджений у вербальний план

10 В. Н. Топоров, Пространство и текст..., цит. праця, с. 247.

11 В. Н. Топоров, О пространстве, пути, великих текстах..., цит. праця. 
творів, наділений важливою місією: за допомогою одного простору передається скрите і невидиме другого простору.

Слова підтвердження знаходимо у наступних рядках:

Душа звичайно бродить між двох невидимих світів.

(Що той таємниця, що інший - холодна загадка). (124).

Оскільки слово (чи текст) вважається просторовим, тому є відкритим і вільним, а отже, може стати образом для самого простору, його твором (згідно хайдегерівської манери висловлюватись). У такому значенні можна говорити про простір, який описує самого себе, про частину, яка говорить про загальне, до якої сама належить ${ }^{12}$. У ліриці Антонишин маємо змогу зануритися у драматизований динамічний простір задзеркалля, який є основною темою збірки Свіча-До-Ля і переданий за допомогою лапідарності тексту, багатих онтологічно метафор, називних речень та згущених емоцій самої поетеси, що породжує сугестивність поетичного твору.Через категорію простору, у даному випадку нереальний простір задзеркалля, ліричний текст виходить за рамки самого себе i творить складний локусний комплекс. У цьому контексті читання лірики Антонишин можна розглядати як замикання того, що є тут, $з$ тим, що $є$ там, підштовхуючи читача до зрозуміння, що простір задзеркалля можна трактувати як вагому частину життєвого простору поетеси.

\section{БІБЛІОГРАФІЯ}

Antonišin Svitlana. 2017. Sviča-Do-Lâ. Kiïv: Ukraïns'kij prìoritet [Антонишин Світлана. 2017. Свіча-До-Ля. Київ: Український пріоритет].

Čulkov Oleg. 2000. «Živye zerkala». Mifologiâ $i$ metafizika otražennogo. $\mathrm{Al}^{\prime}$ manah«AKA $\triangle \mathrm{HMEIA».} \mathrm{Materialy} \mathrm{i} \mathrm{issledovaniâ} \mathrm{po} \mathrm{istorii} \mathrm{platonizma} \mathrm{vyp.} \mathrm{3.} \mathrm{V:}$ http://platoakademeia.ru/index.php/ru/academeia/item/39-academeia_3_10, [Dostup: 19.08.2020] [Чулков Олег. 2000. «Живые зеркала». Мифология и метафизика отраженного. Альманах«АКААНMЕIА». Материалы и исследования по истории платонизма вып. 3. B: http://platoakademeia.ru/index.php/ru/academeia/ item/39-academeia_3_10, [Доступ: 19.08.2020].

Korenovs'ka Leslava. 2013. Metamova poezï Svitlani Antonišin. "Dzvìn” (Časopis Nacìonal'noï Spìlki pis'mennikìv Ukraïni) № 7 (837): 139-146 [Кореновська Леслава. 2013. Метамова поезї Світлани Антонишин. “Дзвін” (Часопис Національної Спілки письменників України) № 7 (837): 139-146].

Korenovs'ka Leslava. 2015. Prostìr vnutrišn'ogo svitobačennâ Svitlani Antonišin. "Slovo ì Čas” № 5 (653): 16-28 [Кореновська Леслава. 2015. Простір внутрішнього світобачення Світлани Антонишин. “Слово і час” № 5 (653): 16-28].

12 В. Н. Топоров, О пространстве, пути, великих текстах..., цит. праця. 
Lotman Ûrij. 2000. Semiosfera. Kul'tura i vzryv. Vnutri myslâsih mirov. Stat'i. Issledovaniâ. Zametki (1968-1992). Sankt-Peterburg: Iskusstvo-SPB [Лотман Юрий. 2000. Ceмиосфера. Культура и взрыв. Внутри мыслящих миров. Статьи. Исследования. Заметки (1968-1992). Санкт-Петербург: Искусство-СПб].

Poeziâ Svitlani Antonišin ustami pracivnikìv Brodivs'koï CRB. V: https://www.youtube. com/watch?V=Rwxbw2ru_rw, [Dostup: 12.10.2020] [Поезія Світлани Антонишин устами працівників Бродівської ЦРБ. B: https://www.youtube.com/ watch?v=RwxBW2ru rw, [Доступ: 12.10.2020].

Toporov Vladimir. 1983. Prostranstvo i tekst. V: Tekst: semantika i struktura. Red. Civ'ân T.V. Moskva: Nauka: 227-284 [Топоров Владимир. 1983. Пространство и текст. В: Текст: семантика и структура. Ред. Цивьян Т.В. Москва: Наука: 227-284].

Toporov Vladimir. 2017. O prostranstve, puti, velikih tekstah, večnoj žizni i bessmertii. $\mathrm{V}$ : https://alekseygodin.wordpress.com/2017/12/08/toporov/, [Dostup: 29.10.2020] [Топоров Владимир. 2017. О пространстве, пути, великих текстах, вечной жсизни и бессмертии. B: https://alekseygodin.wordpress.com/2017/12/08/toporov/, [Доступ: 29.10.2020].

Vitgenštejn Lûdvig. 1958. Logiko-filosofskij traktat. Moskva: Nauka [Витгенштейн Людвиг. 1958. Логико-философский трактат. Москва: Наука].

\section{PRZESTRZEŃ ZALUSTRZANA W POEZJI SWITŁANY ANTONYSHYN}

Streszczenie. Głównym tematem zbioru wierszy Svicha-Do-La Svitlany Antonyshyn można nazwać przestrzeń zalustrzaną, która jest przekazywana poprzez lapidarność tekstu, bogate ontologicznie metafory, zdania proste oraz skondensowane emocje poetki, co rodzi sugestywność tekstu poetyckiego. Przestrzeń zalustrzana znajduje się po drugiej stronie lustra i jest odwrotną projekcją wszystkiego, co wchodzi w obręb przedmiotu i ma możliwość odtworzenia odbicia. Liryka ukraińskiej poetki jest rodzajem próby przekroczenia progu niewidzialnego, swoistym spojrzeniem w lustro wydarzeń, które zostały w przeszłości lub dzieją się teraz, wejściem w wieloaspektowy wewnętrzny świat lirycznego podmiotu w celu odkrycia tajemnic.

Słowa kluczowe: przestrzeń zalustrzana, kontemplacja przestrzeni, interpretacja, wizja poetki

\section{ПРОСТІР ЗАДЗЕРКАЛЛЯ У ПОЕЗІЇ СВІТЛАНИ АНТОНИШИН}

Резюме. Провідною темою поетичної збірки Свіча-До-Ля Світлани Антонишин можна назвати простір задзеркалля, який переданий за допомогою лапідарності тексту, багатих онтологічно метафор, називних речень та згущених емоцій самої поетеси, що породжує сугестивність тексту віршів. Простір задзеркалля - це потойбічна сторона дзеркала. Він являє собою зворотну проекцію всього, що потрапляє у рамки дзеркального предмета, та має здатність відтворювати відбиток. Лірика української поетеси це свого роду спроба переступити поріг невидимого, заглянути в простір задзеркалля подій, які відійшли у минуле або відбуваються тепер, увійти в багатогранний внутрішній світ ліричного героя з ціллю експлікувати все таємне та невимовне.

Ключові слова: простір задзеркалля, інтерпретація, споглядання простору, задум автора 